\title{
Quaternary Glacial History of Naradu Valley, Kinnar Himalaya, Himachal Pradesh
}

\author{
Surendar Singh, M N Kaul1
}

${ }^{1}$ Department of Geography, Jammu University

\begin{abstract}
The Himalayan glaciers, presently confined above the altitude of $4000 \mathrm{~m}$, have existed at the lower altitude levels in the geological past. Glaciers of Quaternary period in Himalaya have retreated continuously with punctuations of minor advances. The evidences of glacial extent and its subsequent retreat can be observed in the form of various landforms in the glacial landscape attributing their origin to glacial and glacio-fluvial geomorphic processes that operated in the geological past. For documenting the palaeoglaciation, it is desirable to have uninterrupted stratigraphic data for a long period. The Quaternary deposits that are main source of data imprints are frequently discontinuous in three dimensions and are a mixture of glacial, glacio-fluvial and fluvial sediments. Thus, the effect of one environment under which the sediments have initially originated gets modified by the influence of other environment, which is responsible for their subsequent transportation and deposition. However, the study of sediments of Quaternary terrain provides a clue to understand the processes in the past and environment in which they originated. Kaul (1990), reconstructed the Quaternary history of Liddar Valley on the basis of pollen analysis, lichenometry, fossil flora and glacial geomorphologic evidences. Dodia, Agarwal and Vora, (1985) gave a summary of climate and geology of Kashmir for last four million years on the basis of pollen analysis of Kashmir Bogs. Mazari, Bagati, Chauhan and Rajagopalam, (1993) recorded their investigation on Trans-Himalayan Lahul-Spiti region and constructed palaeoclimatic record of the area for last 2000 years on the basis of lacustrine facies and pollen analysis. Lewis A. Owen, Christine H. Scott and Edward Derbishire (2000) in their paper on Quaternary glacial history of Nanga Parbat indicated that glacier advanced between $12 \mathrm{~km}$ to $15 \mathrm{~km}$ from present ice front.According to them, the maximum extent of glaciation in Nanga Parbat occurred during the early part of last glacial cycle followed by two re-advances or period of stagnation during Pleistocene/Holocene times. This was formulated on the basis of glacial deposits in the valleys and decline in the sub-glacial component. Koul and Ganjoo (2009), described the Quaternary Glacial History of Baspa Valley based on geomorphological evidences and multiproxy analysis of palaeo lake profile and $\mathrm{C}^{14}$ dating. They suggested two glacial advances followed by gradual three recessions after the second glacial advance.
\end{abstract}

\section{Area of Study}

Naradu glacier valley is situated in the Sangla Tehsil of Kinnaur District of Himachal Pradesh. It is located near the remotest village Chittkul, an offshoot of Hindustan-Tibet Highway-22. The glacier snout located at an altitude of $4392 \mathrm{~m}$ is almost at a distance of $6 \mathrm{~km}$ trek from Chittkul village. Naradu glacier is one of the

89 glaciers of Baspa basin. Baspa basin is the $5^{\text {th }}$ order Basin of Sutlej River and forms one of the largest ice fences of Sutlej. The Naradu glacier is housed in the upper part of the valley commencing from Khimloga range head wall at an altitude of $5600 \mathrm{~m}$. It comprises of two lobes in southwest and southeast direction and descends to merge at an altitude of $5000 \mathrm{~m}$. It flows down a distance of $740 \mathrm{~m}$ in north east direction and then descends down into main valley of the glacier. Extensive crevasses, in the form longitudinal and chevron, occupy this part of the glacier. Icefalls are common in the upper part of the glacier as there is sharp change in gradient and variation in litho logy of the valley. The snout is marked by numerous transverse crevasses and is predominated by supra glacier debris. Below the snout the valley as whole is one of the steepest valleys having a relative relief of $2100 \mathrm{~m}$.

Naradu basin is fenced in the south by two peaks of Khimloga range of Himalaya, which happens to be water divide between Sutlej and Ganga. The basin is connected with Uttarakhand State through Khimloga pass. The glacier proper commences from Khimloga range head wall at an altitude of $5600 \mathrm{~m}$ from a common ice front and descends in two branches in a cirque trough. The two branches merge at an altitude of $4900 \mathrm{~m}$ at the vicinity of ice-fall, and flow down in northeast direction and terminate at an altitude of

This article is published under the terms of the Creative Commons Attribution License 4.0

Author(s) retain the copyright of this article. Publication rights with Alkhaer Publications.

Published at: http://www.ijsciences.com/pub/issue/2017-12/

DOI: 10.18483/ijSci.1039; Online ISSN: 2305-3925; Print ISSN: 2410-4477 
$4392 \mathrm{~m}$. The glacier has length of $5.15 \mathrm{~km}$ and covers an area of $4.56 \mathrm{~km}^{2}$. The longitudinal profile of the Naradu Glacier is parabolic in outline with convexity at trough head and body of glacier has four treads with steps in between. The first tread commences from snout and extends to the altitude of $4520 \mathrm{~m}$.It has gentle gradient and covers area of $19.6 \%$. The second tread extends between the altitude $4560 \mathrm{~m}$ and $4920 \mathrm{~m}$ and covers area of $27.84 \%$ area of glacier. From the equilibrium line at $4920 \mathrm{~m}$ to the altitude of $5080 \mathrm{~m}$, there is another tread of moderate gradient extending between the altitude $5080 \mathrm{~m}$ and $5200 \mathrm{~m}$ covering an area of $12.6 \%$ of the glacier. Above $5200 \mathrm{~m}$ there is steep trough with serrated ridges having an area of $9.7 \%$

The valley is integrated with different micrometeorological elements based upon different microthermal altitudes related to seasonal snow cover, rainfall, temperature variability, solar radiation, sunshine, albedo etc. The detailed analysis of micrometeorological elements indicate that the region has a prolong winter season lasting for seven months. During this season, the temperature varies between $5.5^{\circ} \mathrm{C}$ and $-19^{\circ} \mathrm{C}$. The summer season is short and extends from May to September during which the temperature varies between $22^{\circ} \mathrm{C}$ and $-2^{\circ} \mathrm{C}$. The diurnal range difference between the mean daily maximum and minimum temperature is $8^{\circ} \mathrm{C}$ to $14^{\circ} \mathrm{C}$ during summer season and $-10^{\circ} \mathrm{C}$ to $-3^{\circ} \mathrm{C}$ during winters. Precipitation in the valley primarily occurs in the form of snowfall, and amount to about two-third of the total precipitation. Rainfall occurs only during the summers and is confined to the lower parts of the valley.

The vegetation of the study region reflects characteristic mixture of Temperate and Himalayan flora. The phyto-geographic composition of plant communities is different at different elevations due to microclimatic, biotic and other environmental condition. The lower part of the valley, between the altitude of $3300 \mathrm{~m}$ and $3600 \mathrm{~m}$, is covered by mixed species of oak, Pinus Exelsa and Abies with abundant undergrowth of scrubs. The zone between $3600 \mathrm{~m}$ and $3800 \mathrm{~m}$ is coniferous zone comprising Pinus Gerardiana and Juniperus species. Betula Utilis (Bhojpatra) between the altitude of $3800 \mathrm{~m}$ and $3900 \mathrm{~m}$ forms the tree-line. The vegetation above tree-line up to $4200 \mathrm{~m}$ comprises of bushy vegetation of Rhododendron species, Ribes Glaciale, Ribes Rubrum and Artemisia Meritima. The bushy vegetation gradually merges with Himalayan meadow. The herbaceous taxa consist mostly of Asteraceae, Primulaceae and Saxifragaceae.

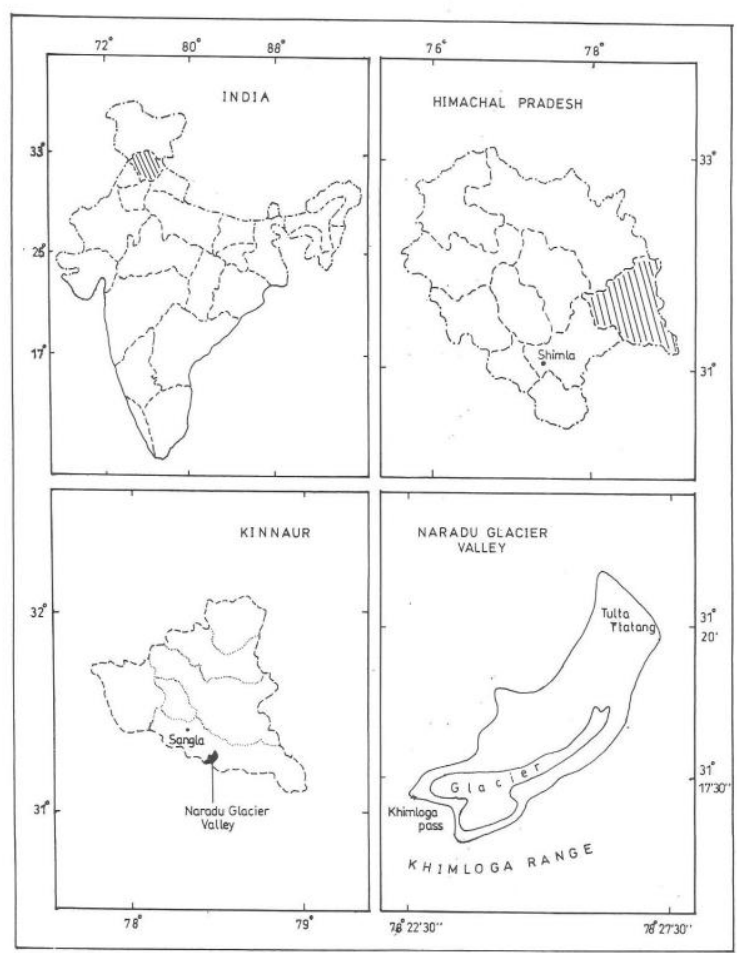

\section{Results \\ Valley morphology}

A major part of Naradu Glacier Valley has a ' $U$ 'shape with ' $\mathrm{V}$ '- shape notch at the lower part. The Naradu glacier housed in the upper part of the valley commences from Khimloga range head wall at an altitude of $5600 \mathrm{~m}$ from a common ice front and descends in two branches in a cirque trough. The two branches merge at an altitude of $4900 \mathrm{~m}$ at the vicinity of ice-fall, and flow down in northeast direction and terminate at an altitude of $4392 \mathrm{~m}$. The Naradu valley profile shows three series of treads separated by stairways at elevations of $4390 \mathrm{~m}$ and $4850 \mathrm{~m}$. The hanging valleys have developed a convex form at the middle and slight concave at the valley head. Overall the profile is comparatively less steep at the upper part than the valley terminus.

Nearly $17 \%$ of the valley is covered by the glacier and rest by glacial landscape. The floor of the valley is narrow and bordered by steep slopes, a mixture of rock faces and high angled scree slopes. Nearly $37 \%$ of the valley sides are covered with scree. Eastern side has a greater cover of scree as compared to the west due to valley orientation with eastern side experiencing longer daily periods of sunshine and resulting in greater degree of weathering as compared to the western side. 


\section{Glacial Geomorphology}

The Naradu Garang Valley is characteristically glaciated having typical $U$-shaped and other features such as hanging valley, polished rock surface and glacier drift depositsssss The polished surfaces with striation markings are preserved along the valley head, valley wall as well as along hanging valleys. The polished surfaces are plentiful in valley at an altitude of $3800 \mathrm{~m}$ along the north east margin. These are preserved on granite and slate. The striations are preserved prominently on Quartzite boulders. The quartzite boulders are frequently striated whereas Phyllites are rarely so. The general direction of striation in the valley is $\mathrm{N} 25^{\circ} \mathrm{W}$. Roche moutonnees are observed at few sites, majority of them at two elevations $3680 \mathrm{~m}$ and $3900 \mathrm{~m}$. The moutonnees are $50 \mathrm{~m}-60 \mathrm{~m}$ long, $10 \mathrm{~m}$ wide and $15 \mathrm{~m}-20 \mathrm{~m}$ high from valley floor. Their stoss side slope ranges between $30^{\circ}$ to $40^{\circ}$ and lee side $60^{\circ}$ to $70^{\circ}$

The glacial depositional landforms in Naradu valley vary in morphology and have complex evolution. These are produced due to deposition of debris through different processes related to their location at or inside the glacier margins in active or stagnant ice. Moraines are the most eminent depositional features that can be seen in the valley. Major part of the valley is covered by moraines arranged in ridges parallel to the sides of the valley. These ridges stretch from an altitude of $4800 \mathrm{~m}$ to $3600 \mathrm{~m}$ in the valley. There is large tract of fluted ground moraines in the vicinity of Tulathang $(3580 \mathrm{~m})$.It covers an area of $425 \mathrm{~m}^{2}$.In this morphological division there are well developed $3 \mathrm{~m}$ high linear furrows. The surface is covered with rounded boulders of crystalline, sandstone and phyllites. The crystalline are prominent in proportion (40\%). The outline of this feature is rolling in nature and it is attributed to pressing of debris in channel cavities under ice and presently the area is covered by vegetation and is stabilized.

\section{(a) Cirque}

Five cirques have been observed in the Naradu valley. Two large cirques are located at higher altitude (upper section of valley) between $5400 \mathrm{~m}$ and $5100 \mathrm{~m}$. These two cirques house the two accumulation lobes of Naradu glacier from where the glacier proper commences. Cirque stairway has been identified in the right lobe cirque of the glacier. The cirques in this section of the valley have southwestnortheast orientation. Two cirques are located in the middle section of the valley between the altitude zone of $5000 \mathrm{~m}$ and $4640 \mathrm{~m}$ along the western margin of the main glacier. One out of these two cirques, one is occupied by ice and other is ice free. The ice-free cirque in this section has southwest-northeast orientation and is covered with rocks and scree.

\section{(b) Lateral Moraines}

Lateral moraines in the valley extend from an altitude of $4900 \mathrm{~m}$ to an altitude of $3600 \mathrm{~m}$. They exist as elongated ridges along western side of glacier valley. Only a small section from an altitude of $4560 \mathrm{~m}$ to $4510 \mathrm{~m}$ along eastern side of the valley preserves lateral moraines. Moraines are breached at several places by scree cones or fluvial regimes and cover an area of $6.9 \mathrm{~km}^{2}$. They show distinct gradation in height and width from the valley head to valley bottom. Three levels of lateral moraines have been observed in the Naradu valley. The low lateral moraines extend from an altitude of $4900 \mathrm{~m}$ to $4510 \mathrm{~m}$ along the western margins of the Naradu glacier. In the vicinity of $4900 \mathrm{~m}$, their height is about $20 \mathrm{~m}$ and it gains to $38 \mathrm{~m}$ at $4510 \mathrm{~m}$ altitude. They have slope of $40^{\circ}$ to $60^{\circ}$. Medium-high lateral moraines are present between altitudes of $4580 \mathrm{~m}$ to $4020 \mathrm{~m}$. Their height is $40 \mathrm{~m}$ to $80 \mathrm{~m}$ and have slope of $25^{\circ}$ to $35^{\circ}$. The high lateral moraines are nearly $80 \mathrm{~m}$ to $115 \mathrm{~m}$ high from the valley floor and have a slope of about $15^{\circ}$ to $30^{\circ}$. Similarly the width varies between $35 \mathrm{~m}$ and $68 \mathrm{~m}$.In the vicinity of first hanging valley, the lateral moraines forms arcade loop having box like pattern. From $4900 \mathrm{~m}$ to $4510 \mathrm{~m}$, the lateral moraines have developed lobately pattern, abutting young moraine having height $25 \mathrm{~m}$ and comprising loose angular fragments as compared to consolidated material of older moraines. The lateral moraines of study region primarily comprise rock fragments of crystalline rocks of Vaikrita group (sandstone phyllite, schist and sandstone) and moraine material ranging in size clay to boulder. The highest moraine ridges are stabilized and have $40 \%$ by weight of coarser material with silt and clay than young low moraines containing nearly $90 \%$ weight by coarser material along with coarse sand. The old moraines are confined in prominence in the middle and lower section of the valley. The older moraines have more proportion of finer sediments and are stabilized. They have vegetation growth on them. The uniformity of large coarse fraction in soil matrix of high, medium, and low moraine ridges of crystalline rocks indicate its origin to single advance .However, the extent of medium moraine ridges with low concentration of crystalline rocks having moderate height and high stabilized moraine ridges indicate three phases retreat of glacier.

\section{(c) Medial Moraines}

Three well developed medial moraines run parallel to each other, first one is between an altitude of $4920 \mathrm{~m}$ asl and $4840 \mathrm{~m}$ asl with average length of $700 \mathrm{~m}$ and height of $6 \mathrm{~m}$.The medial moraines comprise of fresh rock fragments with ice cored material at the base suggestive of young age moraines. The second one lies between an altitude of $4750 \mathrm{~m}$ asl and $4580 \mathrm{~m}$ asl and is $900 \mathrm{~m}$ long with an average height of $9.7 \mathrm{~m}$.A third medial is on the east of the glacier between an 
altitude of $4660 \mathrm{~m}$ asl and $4400 \mathrm{~m}$ asl with an average height of $9.85 \mathrm{~m}$ and length of $850 \mathrm{~m}$. The extreme end of medial moraine, in the vicinity of altitude of $4900 \mathrm{~m}$ asl, coincide with present equilibrium-line of the glacier. The medial moraine, between an altitude of $4510 \mathrm{~m}$ asl and $4920 \mathrm{~m}$ asl is situated below the hanging valley revealing the thickness of hanging glacier could be $50 \mathrm{~m}$ or more. A lateral moraine of medium height fuses with the extreme end of the medial moraine in the vicinity of $4580 \mathrm{~m}$.

\section{(d) End Moraines}

End moraines are important geomorphologic feature of glacial deposition form transverse to the ice front. Their formation depends on a precise balance between glacier advance and the rate of marginal wasting. The end moraines are formed by dumping of debris by retreating glaciers. In Naradu valley, the dumped moraine material can be seen in the proglacial area from the altitude of $3500 \mathrm{~m}$ to the snout $(4392 \mathrm{~m})$. They are marked by heaps of rounded and sub-rounded boulders embedded in sand-silt matrix. The glacier melt channel has cut through them. The stony mounds in the vicinity of snout $(4390 \mathrm{~m})$ are about $15 \mathrm{~m}$ to $20 \mathrm{~m}$ high and primarily comprise of angular fragments. The dumped end moraines have been formed due to deposition of glacial drift moving outwards through shear planes at the retreating margins of glacier. These shear planes extend up to bottom of the thin sheet of active glacier near the terminus and as the debris reaches the surface it dumped along the margin of the ice mass, these moraine are formed from altitude of $3580 \mathrm{~m}$ to the glacier snout. Between the altitudinal sections $4150 \mathrm{~m}$ and $4210 \mathrm{~m}$ asl, two end moraines ridges of arcade shape( $60 \mathrm{~m}$ high) parallel in pattern for a distance of $450 \mathrm{~m}$ covering an area of $0.7 \mathrm{~km}^{2}$ are observed .Their origin is to thrusting. Further from $4210 \mathrm{~m}$ altitude to present day snout position (4392m-4395.10m) a series of five moraine ridges have been observed .These moraine are covered by ablation moraine of thin material with ice wedge at depth $1 \mathrm{~m}$ to $1.5 \mathrm{~m}$. Their origin is attributed to strong push of glacier against a narrow and concave topography resulting in increase in thickness of ice that otherwise is thin. The concavity in bedrock is the result of push and pull factor caused by body of the glacier. Three well developed end moraine are seen in the valley at $3750 \mathrm{~m}, 4100 \mathrm{~m}$ and $4200 \mathrm{~m}$ asl suggestive of three recessions.

Near Chitkul,in the vicinity of Rhimdarang and Shilpaya Garang (3450m to $3650 \mathrm{~m})$,terminal recessional moraines are observed. These moraines have joined with right loop of Shilpaya and left lateral moraine of Naradu Garang that resulted in blocking of Baspa river near Mujiling (3520m).

\section{Debris Landforms of Deglaciation Processes (a) Kame Terrace}

The kame terrace in the Naradu valley occurs between the altitude of $4050 \mathrm{~m}$ and $4070 \mathrm{~m}$ in the middle section the valley. It is $300 \mathrm{~m}$ long and has a width of $55 \mathrm{~m}$ to $70 \mathrm{~m}$ forming an arcade shape. It slopes $25^{\circ}$ towards the valley trend, $45^{\circ}$ to esker ridge and $40^{\circ}$ towards the lateral moraine. The orientation of Kame is $20^{\circ} \mathrm{NE}-25^{\circ} \mathrm{SW}$ and it lies parallel to the lateral moraine. Hence it shows close correspondence with the direction of the ice movement. The fabrics of sediments are fine towards the top. There are several kettle holes within a flat patterned ground. The lowest horizon of the Kame terrace is silt-clay to clay in nature suggesting the stagnant conditions of deposition of sediments. It is overlain by bolder conglomerate bed having lenses of fine sand and silt. The top deposit is gravely in nature. The matrix of gravely deposits sediments comprise of coarse sand. The surface of the Kame terrace is covered by grasses. The stratigraphy sequence of the Kame terrace suggests its origin by the deposition of material released from stagnant ice mass.

\section{(b) Esker}

The esker identified in the study area stretches in a curved form from the altitude of $4150 \mathrm{~m}$ to $4260 \mathrm{~m}$. The upper and lower limit of the esker is buried under the terminal moraines at these altitudes. It is nearly $30 \mathrm{~m}$ wide and $3 \mathrm{~m}$ to $10 \mathrm{~m}$ high from the valley floor. The ridge has rounded crest and slope of $35^{\circ}$, the maximum angle of repose of coarser material. The origin of the esker in the Naradu glacier valley is attributed to the glacio-fluvial material released by melt water which has been gradually laid down by thinning of glacier ice laterally in sub-glacial part. The melt- water channels under hydrostatic pressure move upslope explaining the ternd of eskers that are against the topographic slopes opposed to general direction of melt-water flow.

\section{(c) Kettle moraine}

Two kettle moraines have been observed in the vicinity of $3680 \mathrm{~m}$ and $3900 \mathrm{~m}$ confined between two hummocky ridges having a height of $50 \mathrm{~m}$ to $60 \mathrm{~m}$, separated by low relief central axis. The kettle moraines cover an area of $0.12 \mathrm{~km}^{2}$ at $3680 \mathrm{~m}$ and $0.06 \mathrm{~km}^{2}$ at $3900 \mathrm{~m}$. The hummocky ridges have a width of $170 \mathrm{~m}$ to $215 \mathrm{~m}$ and length of $210 \mathrm{~m}$ to $350 \mathrm{~m}$. The low relief central axis is underlain by rolling diamict ( $2 \mathrm{~m}$ to $4 \mathrm{~m}$ thick). The dia-micton is compact and similar to basal till. The outwash is fine grained, mainly silts to silty-sand and contains few clasts of less than $20 \mathrm{~cm}$.

The low elevation lacks high relief topography but is having undulated surfaces with pebble and boulders. At an altitude of $3695 \mathrm{~m}$, a large conical Moulin kame rises to the height of $25 \mathrm{~m}$ and rests directly on 
the top of basal till. The sides of the Moulin kame are at the angle of repose. Exposures in Moulin kame reveals well sorted to poorly sort sand, gravel and laminated clays. The maximum clast diameter is $1 \mathrm{~m}$. The long hummocky ridges border both sides of the depression up to the height of $15 \mathrm{~m}$ to $30 \mathrm{~m}$. A narrow valley having a depression of $20 \mathrm{~m}$ abuts the rocky exposures of valley walls. At an altitude of $3800 \mathrm{~m}$, the steeply sided hummocky ridges have moderate height of $10 \mathrm{~m}$ to $15 \mathrm{~m}$ and in-between these hummocky ridges, there is a low relief central axis located at the north-eastern side of the valley in comparison of large kettle moraine located at eastern side near the entry point of the Naradu valley.

The distribution of sediments in kettle moraines and undulated land form in central axis dotted with roche moutonnees having two sets of striation reflect that Naradu glacier, after maximum extent of $3400 \mathrm{~m}$, retreated leaving behind two sets of medial moraines after thinning of glacier and these two medial moraines turned into two lateral moraine of medium height along the left at $3600 \mathrm{~mm}$. Similarly at $3800 \mathrm{~m}$,it left two subdued lateral moraines. After retreat, the glacier advanced in phases upto altitude of $3800 \mathrm{~m}$ and $3600 \mathrm{~m}$ reworked the lateral moraines and produced complex kettle moraines along with well developed roche moutonnees along the edges of hummocky surfaces.

\section{(d) Debris cones}

The paraglacial debris accumulation occurs mainly between $3400 \mathrm{~m}$ and $4100 \mathrm{~m}$ in the form of debris cone produced by accumulation by frost weathering and reworking of moraine material by deglacial processes. The moraine debris cone and moraine debris slopes are widely distributed paraglacial sediments. At that elevation, the principal hill slopes are: snow and avalanche slope at high altitude $(5000 \mathrm{~m}$ on west flank of accumulation zone of Naradu glacier). It has steep slope of $45^{\circ}$ and is characterized of sheer face with overhanging rock cornices and avalanche chutes produced due to periglacial activity. The other avalanche slope is observed at an altitude $3850 \mathrm{~m}$ slope of Junipers and Betula forest with linear moraine crest line scar on crystalline rock ridge. In the head ward part of the valley at a altitude of 3950 and 4250m two well developed rock shoulders are observed on right wall of the valley developed on slate and phylite rocks .These slopes have typical engraving by glaciers in the form of polish surface, Roche moutonnees outcrops affected by rock topples with structural bedding towards valley ward. Such features suggest that Naradu Garang contained glacier at least $250 \mathrm{~m}$ thick during some stage of Pleistocene/Holocene. The scree slopes are most conspicuous of Naradu Valley landscape and are in the form of strips, lobate, and festoon. Low angled alluvial fan $\left(7^{\circ}\right.$ to $10^{\circ}$ ) observed near broad valleys where melt water streams debouch.

\section{( e Lake deposits}

Two lakes of Quaternary age were identified by team of DST Project at altitudes of $4125 \mathrm{~m}$ and $4325 \mathrm{~m}$ in the Naradu glacier valley. The pollen data of the lake profiles $(240 \mathrm{~cm})$ mainly represent the deposition of clay/silt with occasional lenses of fine sand. The sedimentary characteristics are indicative of calm weather depositional environment conditions. The clay and silt deposits are interrupted by $5 \mathrm{~cm}$ to $20 \mathrm{~cm}$ thick lenses of sand. Texturally speaking, the lake sediments are silty-sand that is moderately to very poorly sorted, finely to symmetrically skew and mesokurtic to leptokurtic and rhythmically bedded with fine sand. The lake deposit is capped by 3 to $5 \mathrm{~m}$ gravel with accumulation of fine sand indicating period of relatively quiescent sedimentation. Two frozen layers, one at the base of profile at the depth of $2.40 \mathrm{~m}$ and the other one between $1.00 \mathrm{~m}$ to $1.45 \mathrm{~m}$ depths, are frozen grounds that contain water mostly in the form of ice.

The pollen data of palaeo-lake of Naradu Garang and its radiocarbon dating document two available dates, one each close to the top and bottom of the profile (Bhattacharya et al.20006).The data shows very high influence of steppe vegetation of extra local and local pollen taxa of Chenopodiaceae, Ranunculaceae, Artimisia, Pine species corresponding to low value of broad leaf taxa that suggest a cold arid climate during 12,720 years to 10,876 years $\mathrm{BP}$.The tree constituents did not grow locally near Naradu Garang but occupied relatively lower altitude slopes of Sangla.This stage was followed by gradual rise of pollen of conifers, Betula, Alnus, and Procaeae, followed by gradual decrease of Chenopodeaceae and simultaneous presence of Salix thereby indicating warm and moist climate around 10,603 to9,928 yrs BP above frozen layer. The pollen data of the next phase indicate increase in Chenopodeaceae, presence of Ephedra and also the decline in Poaceae, Renunculaceae and broad-leaved taxa, suggestive of existence of cool dry climate 9,928 yrs BP to 8,990 yrs. BPin comparison to warm and wet in earlier phase . Though the pollen data in this study provide information for only short span time $(1,650 \mathrm{yrs})$ it holds great significance as there is not much data available covering this period by sediments of Kinnar Himalayan region. The pollen stratigraphy of SanglaKanda (35km SW of region) has been accepted as representative of the region as its pollen stratigraphy closely correlate with study region and provide radiocarbon dating data for prolonged period of 5,000 years( Chakraborti et.al.2006). During this period cool climate was followed gradual increase in temperature assessed on the basis fluctuation in $\mathrm{C} / \mathrm{N}$ 
ratio (Chakraborty et.al. 2006).During this phase there was alternate wet and dry condition as the amount of pollen of Betula and Pinus increased in pollen profile. This phase was followed by gradual increase in temperature leading to warm and moist climate 1800 yrs BP and there after pollen profile shows decreasing trend of conifers and increasing trend in Oak.

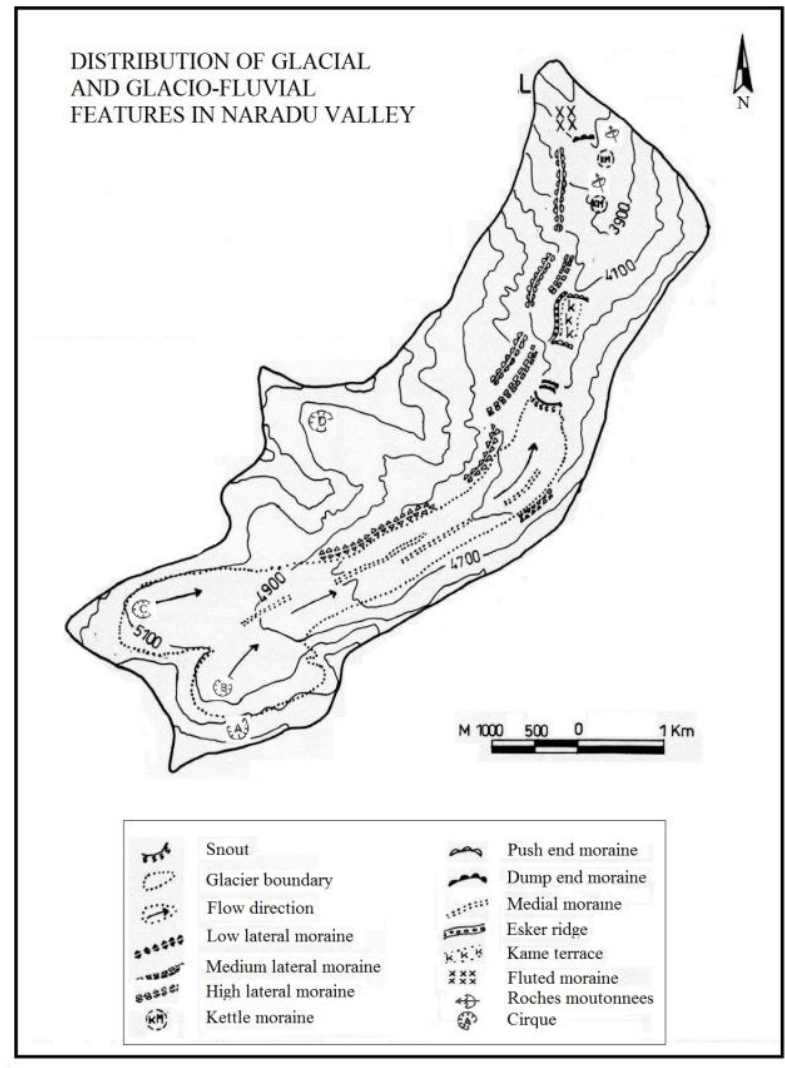

\section{Discussion}

Reconnaissance of the Naradu Garang valley sides from Naradu Glacier down the Naradu River as far as the junction with Baspa River at altitude of 3400m near Chitkul village revealed abundant dissected moraine material ridges $30 \mathrm{~m}$ to $250 \mathrm{~m}$ above the valley floor and periglacier and paraglacier debris. The preservation of polished and striated rock surfaces at valley head, valley walls along hanging glaciers at altitude $3950 \mathrm{~m}$ and on roches moutonnees at two elevation zones one at $4100 \mathrm{~m}$ and other at $3850 \mathrm{~m}$ reflect two glacial advances in the valley. Some roches moutonnees support only rectilinear structural joints that confirms regional structural pattern ,in some roches moutonnees at $3850 \mathrm{~m}$,rocky outcrop affected by rock topples with bedding dipping in valley ward. Further linear moraine scar developed on valley wall of crystalline rocks of rock shoulders at higher altitude gives rough estimated palaeo glacier thickness of $200 \mathrm{~m}$.The two high lateral moraine ridges are suggestive of two glacial advances the outer ridge is older and inner one is younger. The outer moraine ridge extends up to the altitude of $3700 \mathrm{~m}$ and is stabilized with vegetal cover. The field observation temporal changes in glacier extent have been mainly derived from the stratigraphic data confined in lakes located in different altitudes and geomorphological evidences. The main source of data is imprinted in form of climatic flora of the valley. These evidences indicate the climatic changes that have occurred in the area and thereby resulted in the changes in the glacial extent during the Pleistocene/Holocene period.

The analysis of lake deposits correlated with the $\mathrm{C}^{14}$ dating indicates that there were two glacial advances one during 12,720 yrs. BP and other around 10,920 yrs. BP; followed by three inter-glacial stages. At the close of first inter-glacial stage, the climate was mildly temperate. The vegetation constituted of PineOak wood. During the close of second inter-glacial stage the vegetation comprised of Abies and Pinus species. During the last interglacial phase the climate was humid and palaeo-vegetation was in form of pure species of Oak, Pine and Oak and during the present time, the valley has similar vegetation but mixed an impure type of Pine-Oak, Oak-Pine, Pine and Oak. The pollen data provide information for short time span of Early Holocene revealing high amount of pollens of Pinus from the lower elevation along with local trees/shrubs suggest the site was not only closer to tree line but had good coverage of alpine taxa that in turn moved upwards and the region experienced warm and moist condition similar to the recent conditions. The presence of Poacea, Ranunculaceae and fern colonizing along margin of lake throughout Early Holocene indicate moist climate as result of enhanced monsoon circulation as also reported in Ganges ,Brahamputra, and equatorial Africa region (Goodbred \& Kuehl, 2000;Gasse,2000;and Russel et.al.,2003).In Naradu glacier valley the moist phases were interrupted by two phases of semi arid climate due to increase in steppe element (Chenopodiaceae, Artemisia, Ephedra) and decrease in sub-alpine elements, and further corroborated by two frozen layers ( 12,720 yrs BP and around10,100 to11,400 yrs BP) in pollen profile contemporaneous to Younger Dryas episode (Birks \&Birks ,1980;Bradley ,1999;Kar et al.,2001; Sharma et.al.,2004;Juyal et.al.2004; Sinha et.al.,2005).

Multi-proxy analysis of palaeo lake profiles of the Naradu and Sangla-Kanda closely correlated with geomorphological evidences of the study region there by reflect the extension of Naradu glacier to an altitude of $3450 \mathrm{~m}$ to meet the main Baspa Glacier near the village Chitkul $(3450 \mathrm{~m})$ around 12720 yrs.BP. During that period the Naradu Garang was intensively glaciated with extreme cold arid condition resulting in maximum extension of main as well tributary glaciers. Evidence from Tibet corroborate 
the YD (young Drays) event from $12.9 \mathrm{kyr}$ to $12.5 \mathrm{kyr}$ was cery coldin beginning relatively humid $12.5 \mathrm{kyr}$ to $12.2 \mathrm{kyr}$ and again cold and dry until $12 \mathrm{kyr}$ ( $\mathrm{Ji}$ et al2005). Lack of chronometric data from Kinnar Himalaya serves handicap in putting pre-Holocene glacial evidence in chronological order. Nevertheless, taking analogy from Tibet and Pamir (Colgan et al 2006, Owen et al.2003,2005, Zech et al. 2005) it can be argued that extensive glaciations occurred $60 \mathrm{kyr}$,followed by $47 \mathrm{kyr}$, and again glacial advance occurred 18kyr(LGM).

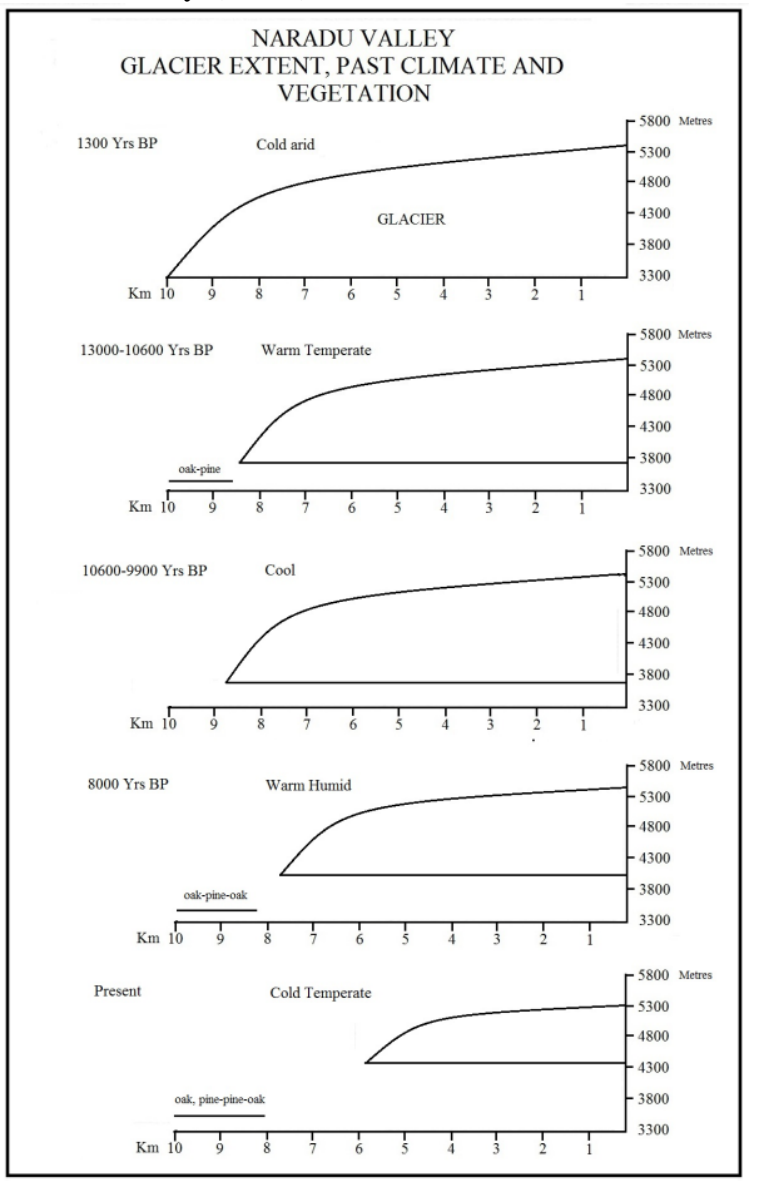

Figure: 3

Warm and moist climatic conditions persisted in Naradu valley during 12,136 and 10,900 yrs BP that resulted retreat of Naradu glacier from Chitkul to Tulthang $(3580 \mathrm{~m})$. The retreat produced large number of fluted moraines and terminal moraines upto 36oom and a Moulin Kame at 3690m is formed due to damming of Naradu by mass transfer of material due reworking of glaciers and by avalanching. During 10,060 yr and 9,900 yr BP resulted in glacial activity that led to advance of glaciers as result of cool and dry climate.

The cool period was followed by gradual increase in temperature during 9,900 yrs to $8000 \mathrm{yrs}$ BP during this period the glacier retreated upwards producing large number of terminal moraines. Latter there was alternate dry and wet condition for prolong period of 5000yrs that produced terminal and recessional moraines resulting in vacation of $3 \mathrm{~km}$ area vertically under Naradu glacier.

\section{Bibliography}

1. Bhattacharya, A., Ranthora, P. S., Ganjoo, R. K. and Koul, M. N. (2006): The Early Holocene vegetation and climate in Naradu glacier valley of Kinnaur District, Himachal Pradesh. Palaeobotanist 55, 89-96.

2. Chakraborty, S., Bhattacharya, S. K., Ranhotra, P. S., Bhattacharyya, A. and Bhushan, R. (2006): Palaeoclimatic scenario during Holocene around Sangla valley, Kinnaur northwest Himalaya based on multi proxy records. Current Science, Vol. 91, No. 6, 777-782.

3. Goodbred Jr. S. L. and Kuehl, S. A. (2000): Enormous Ganges-Brahmaputra sediment discharge during strengthened early Holocene monsoon. Geology, 28, 1083-1086.

4. Lewis A. Owen, Christine H. Scott and Edward Derbishire (2000): The Quaternary glacial history of Nanga Parbat. Quaternary International 65/66, 63-79.

5. Kaul, M. N. (1990): Glacial and fluvial geomorphology of Western Himalaya. New Delhi, Concept Publishing Company.

6. Owen, L. A., Finkel, R. C., Ma, H., Spencer, J. Q Derbyshire, E., Bernard, P. and Cafee, M. W. (2003): Timing and style of late Quaternary glaciation in Northeastern Tibet. Geological Society of America Bulletin 115, 1356-1364.

7. Owen, L. A., Finkel, R. C., Bernard, P. L., Ma, H., Asahi, K., Cafee, M. W. and Derbyshire, E. (2005): Climate topographic controls on the style and timing of Late Quaternary glaciations throughout Tibet and Himalaya defined by $10 \mathrm{Be}$ cosmogenic radionuclide surface exposure dating. Quaternary Science Review 24, 1391-1411.

8. Colgen,P. M., Munroe, J. S. and Shangzhe, Z. (2006): Cosmogenic radionuclide evidence for the limited extent of last glacial maximum in the Tanggula Shan of the central Tibetan Plateau. Quaternary Reaserch 65, 336-339.

9. Dodia, R., Agarwal, D. P. and Vora, A. B. (1985): 'New pollen data from the Kashmir Bogs: A summary', Climate and Geology of Kashmir; the last 4 million years, Agarwal, D. P., $\quad$ Kusumgar,S.and Krishnamurthy, R.V (eds.). New Delhi; Today and Tomorrow's Printers and Publishers, 101-108. 